\title{
ARTICLE
}

DOI: $10.1057 /$ s41599-018-0180-y

\section{The good, the true and the beautiful: imagining an ethico-political future for the philosophy of religion}

Louise Hickman ${ }^{1}$

\begin{abstract}
This article argues that the future of philosophy of religion is ethical and political. Much of the current sense of dissatisfaction felt by both critics and practitioners of philosophy of religion can be traced to a perceived lack of relevance, a problem exacerbated by the diminishing, yet persistent, divide between Anglo-American and Continental approaches. A philosophy of religion that is committed to the Platonic ideals of Goodness, Truth and Beauty offers an ethical and political imaginary that has the potential to make philosophy of religion able to consider the most urgent problems of our age. It is argued here that the work of Pamela Sue Anderson, Douglas Hedley and Mark Wynn encapsulates these Platonic ideals and shows how the philosophy of religion can model itself as truth seeking, innovative and transformative.
\end{abstract}

${ }^{1}$ Newman University, Birmingham B32 3NT, UK. Correspondence and requests for materials should be addressed to L.H. (email: L.Hickman@newman.ac.uk) 


\section{Introduction}

- he first use of the term 'philosophy of religion' in English has been traced back to the seventeenth century Anglican Platonist Ralph Cudworth (Muirhead, 1931, p. 28). His True Intellectual System aimed to establish 'the belief of a God, by philosophic reasons', and thereby deny that it is full of 'inconsistent and contridictious notions' (Cudworth, 1845, I, p. xlviii, II, pp. 509-510). Given the predominance in analytic circles of the rational justification of belief, it is easy to overlook the way Cudworth's main concern was not the justification of propositional belief but the defence of objective goodness against arbitrary will. For Cudworth, and his Platonist contemporaries, philosophising about religious ideas should be concerned primarily with goodness and justice, rather than power. This resulted in a philosophical approach to religion that was inherently ethical and political (Taliaferro, 2005, p. 332). It is the argument of the present article that a recovery of the Platonic concern for the ethical and political should be at the heart of any consideration of the future of philosophy of religion.

Attempting to speculate about philosophy of religion's future prospects brings to mind the hunt for non-existent black cats in dark rooms. Assessing the outlook for the 'discipline' (if there is such a thing) is impossible unless we know something of what we're talking about. Therein lies the difficulty. Like the proverbial cat, there is no consensus about whether a specific discipline of philosophy of religion actually exists and, for those who think it does, a plethora of different definitions abounds (see, e.g., Wildman, 2010). Part I of this article will discuss a perceived lack of relevance, something that has led many to voice their dissatisfaction with philosophy of religion. Part II will suggest, however, that some recent approaches in the philosophy of religion point to a germane and revitalised future, and that these are characterised by a concern for the Platonic ideals of the Good, the True and the Beautiful. Part II will focus predominantly on the work of Pamela Sue Anderson, Douglas Hedley and Mark Wynn as these writers show how philosophy of religion can be revitalised along ethico-political lines through an appropriation of these Platonic ideals. A consideration of their approaches highlights how a philosophy of religion grounded in Platonic principles can respond fruitfully to concerns about the relevance of the enterprise and can do much to dispel the current sense of malaise.

\section{Part l: the future of philosophy of religion and the problem of relevance}

Since Nick Trakakis published The End of Philosophy of Religion (2008) there has been much debate about whether the discipline should have a future and, if so, what sort of future it should be. In his analysis Trakakis identifies two important problems for the philosophy of religion: a marked distinction between analytic and Continental approaches, and the irrelevance of philosophy of religion. Trakakis aims most of his criticism against analytic approaches. He sees a clear distinction between analytic philosophy-with its style of clarity and rigour-and other more integrated approaches most usually dubbed 'Continental', which are not divided so neatly between philosophy of mind, of language and of religion (Trakakis, 2008, p. 34). Crucially, as he sees it, analytic philosophy of religion no longer seeks wisdom or an answer to the question 'how should we live?'. Trakakis' complaint is, most fundamentally, one of relevance. Analytic philosophy of religion has ignored political, ethical and existential problems that used to be the focus of its concerns, and as a result it makes little difference to the way anyone lives their life (Trakakis, 2008, p. 114).

Trakakis was not the first to raise these issues as fundamental problems. He follows Michael Levine who, at the turn of this century, described Christian analytic philosophy of religion as exhibiting a 'lack of vitality, relevance and "seriousness" ' (Levine, 2000, p. 89). More recently the former Christian minister-turnedatheist John Loftus has gone as far as demanding an end to the teaching of the subject, which he dismisses as Christian apologetics (2016). The debate has started to populate the internet too: Justin Weinberg has called attention to an increasing amount of discussion online about whether the philosophy of religion should still be taught (Weinberg, 2014).

In the midst of these calls to abandon the discipline a significant degree of soul-searching has ensued. Those who selfidentify as philosophers of religion have spent a great deal of time reflecting on the legitimacy, nature and scope of their professed area of expertise. That there is a significant level of dissatisfaction with the status quo is illustrated by the use of the prefix 're' in various recent publication titles: an attempt to breathe new life into philosophy of religion and imagine a different future. Graham Oppy wants to 'reinvent' the subject (2014), Paul Draper and John L. Schellenberg's edited volume seeks 'renewal' (2017) and Jim Kanaris, responding in part to an 'identity crisis' in the philosophy of religion, goes for 'reconfiguration' (Kanaris, 2018, p. ix). This language makes it clear that the current state of play is not to everyone's satisfaction and that there are deep-seated issues that need to be addressed. The reconfiguration sought by Kanaris' volume is motivated, as the contributors see it, by a concern that philosophy of religion should have continued relevance (Kanaris, 2018, pp. xv, xvii), while Thomas Carroll has called relevance the most pressing problem of the philosophy of religion, one made evident by the increasing marginalisation of philosophy of religion by those working in philosophy and religious studies. Philosophy of religion, he says, seems to have less and less to add to debates of social interest (Carroll, 2016, p. 41).

The distinction between analytic and Continental approaches that Trakakis identifies, which he posits as creating the conditions for the irrelevance of analytic philosophy of religion, is arguably less pronounced than it used to be a few decades ago but it is still very much in evidence, making up much of the landscape of current reflection on the nature and purpose of philosophy of religion. Kanaris' edited volume (2018), for example, assumes such a distinction as does Draper and Schellenberg's collection (2017). There are identifiable differences between those whose thought is shaped by writers of the European Continent (including Nietzsche, Freud and Heidegger) and those who have adopted the justification of belief through reason as a principal concern, promoted mainly by British and American philosophers. These differences have produced something of an impasse in which each approach has a tendency to deny the legitimacy of the other. Many Anglo-American philosophers of religion struggle to accept that the Continental approach could be classed as philosophy of religion. They tend to assume that religious assertions should be analysed with the tools of reasoning associated most closely with mathematics, logic and the sciences-including coherence, inference and simplicity-with the aim of satisfying the desire for knowledge and justifying belief evidentially. The scope of this tradition has been broadened in recent years, for example through the inclusion of insights from the cognitive sciences, anthropology and psychology (e.g., Nagasawa, 2012), but it is still dominated by a commitment to utilising reason for the understanding of religion and for the testing and justification of religious belief. Those who follow the Continental philosophers often despair at what they see as the reticence of analytic approaches to contemplate different ways of knowing. Their inherited legacy of the death of God has resulted in a loss of confidence in reason, epistemology, ontology and representation 
replaced by an appreciation for reason's social, psychological, cultural and gendered preconditions (Mooney, 2014, p. 73).

Rethinking the philosophy of religion in a way that overcomes or destabilises the distinction between analytic and Continental approaches is essential for imagining a healthy future for philosophy of religion. Timothy Knepper has gone as far as to claim that that neither approach is really philosophy of religion at all (Knepper, 2014, p. 144) while Wesley Wildman highlights a loss of disciplinary identity and unified vision due to the lack of consensus about method, aims, subject matter and scope (Wildman, 2010, p. x). It is essential therefore for philosophy of religion to seek a more unified idea of its purpose. Furthermore, this purpose must address the issue of relevance. As Trakakis points out, it is not clear that we can turn to Continental approaches for an easy fix on this matter. The problem of relevance that Trakakis and Levine identify with analytic philosophy of religion has also been a feature of Continental approaches. Victoria Harrison has reported a sense of crisis felt by many in the field in no small part due to a sense of the discipline's irrelevance beyond its own parameters (Harrison, 2011, p. 29). She identifies urgent questions that philosophy of religion must respond to including those arising from tensions between religious belief and science, from the interaction of people from different religious traditions, from religious convictions motivating extremism, and from how to explain faith in a twentieth century intellectual context (Harrison, 2011, p. 42).

It is the proposal of this article that the task of thinking about the future of philosophy of religion and addressing the problem of its relevance will be better served if its ethical-political nature is more fully esteemed. Thinking philosophically about religion is inescapably ethical and political, whether this is recognised or not. Acknowledging this fact presents an opportunity to reinvigorate the discipline and helps to unsettle any assumption that analytic and Continental are intractably opposed. Furthermore this article will show how Platonic philosophy can be helpful for the task of re-imagining the philosophy of religion as an ethicopolitical enterprise. Cudworth's ethical approach to philosophy of religion has its roots in the Platonic maxim that the most important human question is 'how should I live?' He argued against atheist materialists and Calvinists alike to defend belief in immutable value, insisting no power-human or divine-can turn right into wrong or create truth. That reason can investigate religious claims, for Cudworth, ensures that the will of those who have power cannot determine the nature of religious truth. Contrary to Hobbes' suggestion, goodness and justice are immutable, not subject to will, which means religion is not determined by the 'fiction or imposture of politicians' (Cudworth, 1845 , II, p. 625). In so arguing, Cudworth made philosophising about religion a political act, a direct challenge to the automatic authority of government in the leviathan state (Hickman, 2017, p. 79).

This ethico-political focus of philosophising about religion can be traced back to Plato himself. Plato's Laws puts forward an argument that if the gods exist, they care for human beings and cannot be corrupted (Hedley, 2007, p. 161; Plato, 1975, Book X, esp. \$907). The heart of the argument is ethical: if the power of the gods is not arbitrary, they cannot be bribed. Ethical action cannot, therefore, be reduced to the power of persuasion. An ethico-political orientation can be detected in Neoplatonic thought too. As Stephen Clark points out, the Plotinian (often mistranslated) flight of the 'Alone to the Alone' does not instruct an escape from this world to another but rather demands a reorientation towards the current reality. Metaphysics is thus ethics, and the task of understanding reality means understanding how to live our lives (Clark, 2009, p. 27).
Part II will trace key Platonic ideals in three contemporary philosophers of religion and will show how these principles can play a vital role in re-imagining the philosophy of religion as ethico-political. As Pamela Sue Anderson argues, philosophers need to be asked to reflect on the value-laden nature of doing philosophy if they are to remain true to philosophy's self-definition: 'A return to the ancient practice of reflection on morality and justice would help each and every philosopher to see anew the strengths and weaknesses in the shape of the field' (Anderson, 2012 , p. 31). An ethico-political philosophy of religion can disrupt the fragile distinction between Anglo-American and Continental traditions of philosophy of religion and it can make a valuable contribution to some of the most pressing issues of our age.

\section{Part II: a platonic vision for the future of the philosophy of religion}

Pamela Sue Anderson, Douglas Hedley and Mark Wynn echo Cudworth's appreciation of the profound ethical implications of philosophy of religion and his insistence on the reality of truth and value. Their work will form the focus of the rest of this article, which will examine their commitment to each of the Platonic principles of Truth, Goodness and Beauty in turn. Although their writings have very different foci-for Anderson: gender, oppression and intersubjectivity; for Hedley: image, imagination and sacrifice; for Wynn: place, emotions and the sensory experiencebroad themes of agreement can be identified. They press for what has been called an 'opening out' of philosophy of religion by bringing new issues to bear on philosophical reflection on religion (Carlisle et al., 2011, p. xvii). In addition to this, the centrality of Truth, Goodness and Beauty in their approaches illustrates how an ethico-political turn offers extensive scope for philosophy of religion's renewal and continued relevance.

Truth: resisting illusion and overcoming power. Anderson, Hedley and Wynn promote an approach founded on the reality of truth perceived by reason. As this section will show, however, they offer a much broader account of reason than that typically promoted by analytic philosophy of religion pursuing instead the possibilities of reason as embodied. This leads them to an embrace of epistemic humility: truth is crucial but it continually escapes us. As a result, all three writers promote a conception of truth that has much in common with Platonic thought.

The search for 'Forms' or 'standards' is linked throughout the Platonic corpus with a critique of conventional religious meanings (Corrigan, 2012, p. 20). This is the central concern of the Republic. The allegory of the cave, with its depiction of a 'reality' outside the cave independent of what the prisoners think of it, is presented as part of a discussion about the organisation of the polis in response to Thrasymachus' suggestion that justice is in the interests of the stronger. The allegory suggests that truth and value stand together impervious to the machinations of the sophists. This forms the basis for Cudworth's claim that truth is immutable: the power to persuade cannot turn falsehood into truth or wrong into right. Kevin Corrigan explains how the search for a higher standard in the Republic prompts a critique of conventional myths about the wrongdoings of the gods and about human immorality disguising itself as morality. The 'Good' in the Republic therefore allows for a 'new indeterminacy' of what is more ultimate set against traditional received representations of the gods (Corrigan, 2012, p. 23). Philosophising about religion is thus conducted as the search for truth beginning with the unmasking of illusions.

This interpretation of Platonism lies at the heart of Hedley and Wynn's philosophy of religion. The rise and fall of the soul in the 
Phaedrus' myth of the charioteer is a crucial image for Hedley and conveys the Platonic conviction that there are more and less truthful ways of apprehending reality (Hedley, 2008, p. 162). This is the key mythos of Plato's cave allegory: real progress towards the ideal is possible with effort (Hedley, 2008, p. 170). The same allegory is also central to Wynn's Renewing the Senses (2013) wherein he brings his earlier work on emotion and place together with a rendering of Plato's cave to affirm the 'shadows' or senses as conduits of enlightenment infused with insight and wisdom (Wynn, 2013, p. 15). In doing this he is concerned to argue against projectivism and presents an epistemic case for religious belief that seeks to establish its truth. Appearances are no longer deceptive when they are structured by a true conception of the nature of things (Wynn, 2013, pp. 82, 127). This presents an optimistic account of the human condition but it also emphasises the struggle needed to attain 'enlightenment' by overcoming deception. Most fundamentally, a commitment to what is real is the only thing that can galvanise the determination to go beyond mere images, and overcome ignorance and deceit.

An expanded conception of reason is a notable characteristic of Hedley's conception of the imagination. By way of navigating the tension apparent in Plato's account of knowledge as rational in character and essentially teachable (promoted by the Republic), but also as beyond expression and definition (contained in the treatment of myths, for example in the Phaedrus), he incorporates the tools of rationality into a philosophy of the imagination (Hedley, 2008, p. 14). This enables him to develop what he calls the Platonic via media between rationalistic reductionism-which rejects anything that cannot be verified or logically analysed-and a-rational subjectivism or anti-rational fideism (Hedley, 2008, p. 22). Reason is the lynchpin of his philosophy of religion but it is reason envisioned as imagination or, as Wordsworth puts it, 'reason in her most exalted mood' (Hedley, 2008, p. 22). Hedley develops an account of the potential for art or nature to serve as image of the divine through the activity of imagination. Images are the symbols of a higher reality and channels of discernment: they participate in what they symbolise. As explored further in the section on Goodness below, this enables nature to be an icon of the divine (Hedley, 2016, p. 147). The imagination thus enables an agent to respond and engage fully with the world in a way that a purely cognitive reaction could not (Hedley, 2016, p. 175).

Hedley himself draws attention to the way imagination is akin to what Wynn calls 'thought infused seeing' (Hedley, 2016, pp. 178-179) and close similarities can be drawn between them. Wynn argues that the embodied nature of knowledge means it cannot be grounded in disembodied abstract rationality but must have an irreducible 'emotional' component. A change in emotion can change the appearance of the sensory world (Wynn, 2013, p. 23). Applied to knowledge of place, this means knowledge cannot be expressed purely in abstract linguistic terms because it requires reference to emotions (Wynn, 2009, p. 28). Emotional feelings can be realised in the patterning of the perceptual field: they can 'spread themselves' upon the world meaning a feeling of joy is accompanied by an experience of joy in the objects that surround the perceiver (Wynn, 2013, p. 36). In this way, Wynn explains how feelings can reach beyond an individual and into the world. A link is drawn between emotions, the senses and embodiment, which leads him to propose that our encounter with the realm of sensory forms is the channel of the most vivid religious insights. Both Hedley and Wynn therefore insist the 'shadows' of sensation are indispensible and not subservient to a realm 'beyond'. Embodiment is not something to be despised or overcome. They propose instead an epistemology that suffuses our encounter with the world with spiritual concerns.

The experience of the Gothic church (first proposed by Roger Scruton) utilised by both Hedley and Wynn helps to explain this.
As Wynn puts it, the experience of the church is organised according to the concept of the heavenly city, which enables the building to function as an image of the heavenly city (Wynn, 2013, p. 47). The non-observable thereby structures the reality we experience through the senses. In Hedley's terms, the Gothic church serves as image or icon, not merely representing the divine but participating in it. Furthermore, the mediating capacity of the imagination more broadly is akin to the Gothic church (Hedley, 2016, pp. 254-255). The idea of God is mediated through the human imagination in the way we 'imagine' other minds or moral facts, making the imagination the presence of the transcendent ideal in the world of senses. The intellectual and the physical, reason and sense, are therefore brought together in what Wynn calls the 'religious-thought-infused perceptual gestalt' (Wynn, 2013, p. 91) and what Hedley describes as the contemplative activity of imagination.

On this approach, it is not inference that leads us from the natural world to the divine any more than it leads from the Gothic building to the heavenly city. Belief in God is neither a purely intellectual exercise nor a given of human awareness (Hedley, 2016, p. 259). This collapses the dichotomy between reason and sense and is a direct consequence of Hedley and Wynn's Platonic model. Wynn is right that Plato's Republic invites us to reconsider the relationship between the phenomenology of our experience of the sensory world and our spiritual development. As Hedley points out it is a Plotinian principle that sense and intellect belong on a continuum, a sentiment encapsulated by Cudworth's Platonist contemporary John Smith: 'when reason once is raised by the mighty force of the Divine Spirit into a converse with God, it is turned into sense' (Hedley, 2016, pp. 19, 254). Hedley and Wynn therefore do much to show how a strong account of reason does not have to eschew the emotions or senses but can endorse them as conduits to truth.

Some caution must be exercised with regard to the appropriation of Platonism. Jantzen holds Plato in large part responsible for the necrophiliac tendencies of western philosophy, which she depicts as grounded in a dualism between matter and spirit, body and reason (Jantzen, 1999, pp. 137-139, 2004 esp. chapter 10). Furthermore, Harriet Harris notes that many feminist philosophers are cautious about ideals of truth-seeking because claims to truth have so often been oppressive (Harris, 2001, p. 40). Platonism, however, contains the seeds of a radicalism that could incorporate concerns for race, gender and other injustices. Corrigan explains how for Plato's Laws, proper service to 'the gods' is to 'overthrow our prejudices, to subvert our notions of position, power, and morality' and to call all human beings to what is really important: not external signs of rank but openness to a reality that saturates and sustains the whole of nature (Corrigan, 2012, p. 20). This forms the basis of the Plotinian principle that the Good and Beautiful belong exclusively to nobody, and that the dialectical movement toward being is never accomplished (Corrigan, 2005, p. 129; Plotinus, 1966, III.8.11, pp. 23-24).

The spirit of Platonism interpreted in this way has much in common with Pamela Sue Anderson's philosophy of religion. Her prioritising of truth is not Platonically inspired but it is in harmony with the Platonic rejection of ethical relativism and the recognition for relativism's potential for the abuse of power. She distances herself from poststructuralism and the 'difference feminism' of Irigaray arguing that historic notions of epistemology, realism and rationality are not inherently male or the enemies of women in philosophy but remain necessary for revisioning gender in philosophy of religion' (Anderson, 2012, pp. $135,183,197)$. In her distinction between the aspiration to become infinite and the craving for infinitude, she illustrates how the philosophy of religion can retain a strong view of truth while 
remaining sensitive to the potential for oppression. The urge to become infinite, she says, is the desire to be all-knowing, allpowerful and all-good, and it is this that has so often motivated Anglo-American philosophy of religion when it assumes that the tools of rationality can access the view from nowhere (Anderson, 2001 , p. 13). The yearning for infinitude, on the other hand, is what motivates the search for truth, goodness and justice (Anderson, 2001, p. 4). Truth, on this view, acts like an infinity point, strived for but always beyond the grasp and impossible to encompass. It is this yearning that drives the philosophical endeavour and it is ethical in nature. A philosophy of religion that practices the yearning for truth will not rest with the justification of belief but will, as Anderson points out, become a moral and spiritual enterprise. Truth is essentially ethical: to make community, we need to be able to know truth, to speak openly and honestly. Truth-telling has to be a spiritual practice for many of us because we live and work in settings where falseness is rewarded, where lies are the norm' (hooks, 1999, pp. 120-121).

There is a notable difference in the way Anderson applies her principle of seeking truth when compared to Hedley and Wynn. The yearning for perfect rationality in her view motivates us to confront our situatedness and the limited knowledge it grants us (Anderson, 2012, p. 127). She calls us to become more mindful of how our social location, gender and race shape our philosophical concepts in aesthetics, religion, metaphysics, morality and politics (Anderson, 2012, p. 169), a concern that Hedley and Wynn pay little regard to. Unlike Anderson, neither is concerned principally with interrogating religious beliefs and practices from the perspective of race or gender. By virtue of its Platonic hue, however, Hedley and Wynn's approach remains open to incorporating Anderson's call. The yearning that she speaks of describes an important feature of Platonic rationality: that as humans we see shadows and we cannot forgo our epistemic humility. The search for truth is thus a struggle because we are compelled to scrutinise our experiences, rationality or beliefs by remaining sensitive to their contextual influences. Despite their differences, therefore, there is scope to harmonise their approaches.

Further harmony between Anderson's approach and the spirit of Platonism can be discerned in the way that the seeking of truth cannot be done alone. For the Platonist, philosophy is not a 'means of penetrating the heavens on the basis of our own wishful contemplations' but a practical, contemplative form of ascēsis which is to be undertaken as a life-long pursuit of divine wisdom by two or more partners (Corrigan, 2012, p. 23). Plato wrote dialogues in the form of stories (mythos), and through the practice of dialectic, he turns philosophy into what Corrigan calls a 'form of lived community experience' that opens up a new intermediate space for both thinking and practice, which casts familiar categories and representations of divinity into doubt (Corrigan, 2012, p. 23). Genuine dialogue involves openness and risk: neither party knows exactly where it will take them. The practice of philosophy as dialectic is never in the power of those who undertake it but requires some sort of open-ended orientation to the Good, which itself always remains beyond being (Corrigan, 2012, p. 26). This presents a radical model for a philosophy of religion entirely in keeping with Anderson's broad aims. Corrigan affirms the potential for dialectic to open up a space that supplants any privileged position. It is 'the stranger'female or male-who becomes the major conversation partner in the Symposium and later dialogues, and who assumes the 'hierophantic role of linking the whole community to the divine' (Corrigan and Harrington, 2013, p. 266)

For Anderson, it is not merely being embodied that matters but the struggle for what she calls a feminist standpoint. This is achieved 'by, or on behalf of women and men who have been exploited, oppressed or dominated' (Anderson, 2001, p. 7) and it cannot be done alone. The philosophy of religion, together with the religious beliefs it interrogates, must be reconfigured by reading texts and images of women not from the standpoint of male-neutrality but from the standpoint of those who have been 'othered' and subject to oppression. In order to do this, the imagination is crucial. Adopting Arendt's re-reading of Kant's sensus communis, and her idea of the free play of the imagination, Anderson proposes a productive form of mimesis (Anderson, 2001, p. 13). Rather than transpose ourselves into the standpoint of the other we should imagine possible intermediary positions that give a better understanding of the self and the other. It is through the imagining of possibility that we can reach a less biased epistemic perspective. The search for truth and the practice of imagination is thus a collective enterprise for Anderson.

This call for us to think from the lives of others to achieve greater truth (Anderson, 2001, p. 7) is thus compatible with a Platonic dialectic interpreted along Corrigan's lines. Corrigan affirms that Plato presents a model for the radical destruction of conventional religious representations on an unprecedented scale in order to let new light shine and create new ways of thinking (Corrigan, 2012, p. 23). If such dialectic pays true regard to Anderson's concerns about race and gender, and if dialogue with the marginalised other is a priority, then a Platonic model of dialectic that employs imaginative thinking has much to contribute to a far-reaching ethico-political philosophical reconception of religious thought.

Although, therefore, Anderson's feminist concerns are absent from Hedley and Wynn's work, by virtue of their Platonism their approaches do not preclude it. Hedley allows for transformation in his account of the imagination and-along with Wynn-in his account of how concepts shape perception (Hedley, 2016, p. 252). All three writers thus show how the imagination is crucial for critiquing the way we think and seek to know. This is an important insight and demonstrates that the way we think is even more fundamental than the religious ideas we have. This is because our beliefs, including concepts of God, cannot be separated from our ways of thinking. Our emotions, for example, determine what questions we judge important to ask and what kinds of answers we will seek (Wynn, 2009, p. 28). Anderson points out that yearning for truth is, by its nature, an emotive state: it is desirous and inseparable from our embodied being. In place of a highly abstract understanding of rationality, she insists emotions and embodied experience are essential to the process of gaining knowledge (Anderson, 2012, p. 111, 2001, pp. 8-9). Like Hedley and Wynn she insists embodied knowledge is more truthful. All three thinkers show how philosophy of religion must include critical reflection on our conceptual schemes including the way we reason.

This discussion about truth has shown that a commitment to truth is an important aspect of an ethico-political philosophy of religion. As bell hooks puts it, the pursuit of truth is the only thing that can counter the addiction to lying and denial that cultures of domination promote (hooks, 1994, p. 28). This principle underpins Harriet Harris' argument that only truth can subjugate power. If truth and knowledge are created, it becomes difficult to claim that oppressive practices are wrong and impossible to bring our communities to judgement by speaking truth to power (Harris, 2004, p. 82). For Hedley and Wynn's interpretation of Platonism, and for hooks and Anderson, an enhanced capacity to turn from sophistry and face reality becomes possible. All four thinkers reject fideism and refuse to shun reason entirely as a conduit to truth. Our capacity to attain knowledge is not, they might say, irredeemably limited and context-dependent. At the same time, they shun the scientific model of rationality and the method of inference espoused by so 
many in the Anglo-American tradition. In its place they propose a greatly expanded conception of reason that challenges any sharp distinction between reason and our embodied sensory experiences. Rather than promoting detachment from the body, they see embodied experience as essential for the pursuit of truth. Without this conviction in the reality of truth, contemporary philosophy of religion has no way of offering a substantial challenge to the prevalent collective cultural consumption of misinformation and lies. Any philosophy of religion that is ethically engaged must, therefore, be engaged in the practice of seeking truth.

Goodness: transformation and re-imagination. For Anderson, Hedley and Wynn, the imagination is the means by which we see the world, and it enables us to know reality more or less truthfully. The discussion will now highlight the way all three see religious knowing as inescapably ethical and relying on the moral effort of the knower. For each thinker the perception of truth is linked to the moral stance of the perceiver, which means in order to see clearly moral transformation is required. In this way, truth pertains to goodness. As the discussion will go on to show, this transformation rests on the rejection of a dichotomy between the material and spiritual. Such a rejection is, contrary to what is often supposed, in keeping with Platonic thought and it points us towards alternative ways of seeing reality as suffused with value. The result is a model of philosophy of religion that has the potential to re-imagine our relationships with others and with the natural world.

Ethical transformation results from employing the imagination in the practice of Anderson's standpoint epistemology. A standpoint approach leads to radical change in awareness as we overcome the partiality in our thinking and become increasingly consciousness of gender and of the hierarchy of values that lurks in philosophical texts (Anderson, 2001, p. 7). Anderson explains how the change brought about by altered awareness is not most fundamentally a change in propositional belief but is rather a transformation of human relations, and relations between the human and divine (Anderson, 2001, p. 10). In instigating this transposition of thought religious knowing is made an ethical practice.

An openness to the way religious knowing brings about transformation is also evident in Wynn's 'affective-practicalcognitive integrity' (Wynn, 2009, p. 9). In challenging both Reformed and evidentialist philosophy of religion, in which God is known simply by looking, he draws attention to the way knowledge can be gained by virtue of our moral, aesthetic and otherwise engaged response to the places we inhabit: it 'may be grounded in an evaluatively committed appreciation of the material world' (Wynn, 2009, pp. 7-8, 13). This affectivepractical-cognitive integrity forges a connection between belief and action through a focus on the implications of the way we are embodied for our beliefs. Using Pierre Bourdieu's idea of habitus, Wynn shows that perceptions are not neutral: some are affectively structured and intrinsically action guiding (Wynn, 2009, p. 39). Knowing is thus grounded in our embodied appreciation of the world making our understanding of the world inherently ethical (Wynn, 2009, p. 126). Enlightenment is thus not simply a movement upwards or inwards, but also a movement 'outwards' and into the realm of the senses (Wynn, 2013, p. 41). The interconnection Wynn affirms between embodied knowledge and ethical action echoes Anderson's call for us to be more mindful of how our social location shapes our philosophical concepts, and demonstrates how revised concepts can in turn transform our social relationships. Our cognitive beliefs are at once both affective and practical in their implications. Wynn therefore strengthens Anderson's case that any viable philosophy of religion must be able to address the way beliefs are ethical in their practical implications.

The same insight is recognised by Hedley. He brings together Wynn's account of spiritual awakening with a Platonic model of transformation, in which spiritual development and enlightenment produce a reciprocal transformation in the appearance of the sensory world (Hedley, 2016, p. 254). What is known is thereby transformed by the ethical transformation of the knower. For Hedley, the patterns, symbols or images we encounter in the world are as a dark mirror or glass to reflect patterns of the eternal archetypes in the divine mind. They are not universals in rebus but images (eikones) or archetypes (Hedley, 2016, p. 131). Drawing on Schelling, he proposes that myths and symbols reveal transcendence and constitute human society (Hedley, 2016, p. 200). In this way myth can be said to play a similar role to Wynn's idea of place in that it mediates our sensory experience of physical reality and, through the imagination, shapes the way we encounter that reality. This brings attention to the fact our evaluative stance determines the way we see the world. The seer who has, in Platonic terms, sight of the Good beyond the cave will see a mirror image of her own enlightened condition: that is, a world infused with value (Wynn, 2013, p. 26).

A Plotinian account of contemplation underpins the importance of transformation. This is more explicit in Hedley's thought but also present in Wynn's. In this model, myths, symbols and images aid contemplation but they are also theurgic in that they help to remake the soul (Clark, 2009, p. 30). This is how the Platonic dictate that philosophy is about becoming divine should be understood. It is an awakening and reorientation, envisaged in terms of becoming aware of the universe as both intelligible and inherently moral. This requires personal transformation (Clark, 2009, p. 32). Like Anderson's practice of mimesis a Platonic account of attention to the experience of reality demands that the knower engage in self-criticism. To attain more being, or fuller being, it is not enough, Plato insists, for the soul to puff itself up like a frog. It must instead be transformed by experiencing a reality outside itself so it does not 'make itself the sole criterion of what is real' (Corrigan, 2005, p. 128). The ethical nature of this transformation is unavoidable. As Hedley puts it, quoting from the seventeenth century Platonist Henry More, 'if thou beest it, thou seest it, as Plotinus speaks' (Hedley, 2016, p. 115; More, 1660, p. 407).

Critical to upholding the ethical nature of contemplative knowledge is a collapse of the dichotomy between the material and spiritual. Plotinus did not posit them as two separate realms, rather as two ways of looking at the same reality. We can, for example, look 'downward' at the world and see it in reductionist terms as disconnected atoms. Looking downward means treating things as meaningless collections of stuff devoid of inherent value and beauty (Clark, 2009, p. 36). Alternatively we can transform ourselves and re-orientate our vision so we apprehend the reality of moral value. It is the Plotinian insistence that the world can be envisioned differently that explains Hedley's claim that human beings are amphibious. Plotinian 'seeing' forges a connection between visible and invisible not through inference or an argument from effect to cause but through phenomenological apprehension (Corrigan, 2012, p. 33; Hedley, 2016, p. 259). The ethical implications of this are clear. The natural world, for example, can either be seen in economic utilitarian terms as a resource, or seen as infused with value and the image of the divine.

This amounts to a robust challenge to any suggestion that utility-what Anderson might term 'self-mastery' (Anderson, 2012 , p. 31)-should be the goal of science or philosophy of religion. Furthermore, it should not shape our interactions with 
nature. Looking 'downwards' is the stance the agent of science adopts when endeavouring to gain control even in her moral life through 'disengagement' and 'objectification' of the world, including her emotions, fears and compulsions (Anderson, 2012 , p. 31). When philosophic knowing adopts this model, it posits a self in isolation in a disenchanted world. Wynn too acknowledges that the scientific model of knowing has deep ethical implications in its reduction of reality to utilitarian value. In the model of inference, the world from which we make our inferences becomes merely a means to the end of religious knowledge with no inherent value of its own. Drawing on the work of Erazim Kohák, Wynn calls attention to two different kinds of perceptual gestalt: one which is typical of a scientific mode of viewing (one that regards things in the world according to their use) and a further kind 'which allows us to bring into focus the higher-order property of being the subject of a life, where the second gestalt subsumes the first' (Wynn, 2013, p. 131). Religious and ethical commitments do not only affect our interpretations of sensory experience but the very appearance of the sensory world itself. He reiterates Anderson's worries about the objectification of the world when he suggests that if the mind begins with the material world and is then carried, via an inference, to a non-material unobserved God as source, then our practical engagement with the material world means nothing (Wynn, 2009, p. 7). This makes a strong case that the philosophy of religion must involve the critical examination of religious thinking: most pressingly of its myths, narratives and imaginary.

Essential for an ethico-political philosophy of religion is the spinning of new imaginaries and stories, including new ways of imagining the non-human world. Anderson, Hedley and Wynn show a great deal of concordance in the way they apply the imagination to transfigure our relationship with the natural world. For all of them, nature has immutable value but is also made the channel of human transformation. Standing in the tradition of Plato whose Timaeus depicts a material world suffused with divine value modelled on ethical archetypes, Hedley represents the material world as a theophany: a mirror of the divine. It is, he says, a 'luminous array of images reflecting (although often enigmatically) the perfect being of the Divine' (Hedley, 2016, p. 139). The physical world itself is icon of the divine archetype. Wynn puts the same vision in terms of a transfiguration of the face of nature. A transformation in a person, 'as they approach the condition of enlightenment, or as they develop spiritually, will make for a reciprocal transformation in the appearance of the sensory world' (Wynn, 2013, p. 41). Far from simply being a movement upwards or inwards, enlightenment is also a movement outwards into the realm of the senses. This does not just take place in an isolated region of experience but involves the whole world, whereby everyday objects and ordinary human beings acquire a new dimension of significance. By such means Hedley and Wynn show how philosophy of religion can foster resistance to the Cartesian programme of control over nature for human interest. Nature is recognised as having value in and for itself. Experimentation for the sake of humans is replaced by the contemplation of natural things for their own sakes. The method of quantification is replaced by awareness that we have something to learn from nature. Philosophy of religion therefore cannot avoid ecology. As Hedley points out, 'there is an ecological dimension to the vision of the created order as image of its source' (Hedley, 2016, p. 225).

This has implications for natural theology. The insights above are in keeping with Anderson's revisioning of natural theology when she suggests natural theologian should ask questions about, among other things, the terms and concepts we apply to nature, to others, to the self and to the divine (Anderson, 2013, p. 355). Employing the imagination in the struggle towards the standpoint of the 'other' is thus essential for philosophy of religion to play its role in thinking critically about how we live and relate to the nonhuman cosmos. Our thinking about nature needs to be transformed by an imagination forged from the struggle for a more truthful standpoint. Allied to this goal, the imagination can also expose the fantasy of a supposed value-free science that excludes religious, metaphysical, moral and political perspectives. Claims to exclude these perspectives actually allow for 'hidden exploitation' by corporate, private or governmental interest groups, many of which are in fact underpinned by theological and religious commitments (Corrigan, 2009, p. 251). The transformation of vision entailed by the creative imagination can thus help to define philosophy of religion's task as that of unmasking illusions and creating alternative ways of seeing. In so doing, reason can help to make ethical sense of the world (Anderson, 2012, p. 111) and help us to know how to live well in it.

The future of philosophy of religion therefore lies in sparking the imagination in order to re-imagine our relationships with one another and the wider natural world. As Eddie S. Glaude points out, the loss of imagination leads to our becoming trapped and complicit in what is familiar because it leaves us unable to visualise any alternative (Glaude, 2016). Scientism and the accumulation of capital are two of the most dominant imaginaries of the current age. They shape our questions, determine our priorities and envision what solutions to our problems are deemed acceptable. We seek mechanistic solutions to our ecological problems because our vision of nature is that of utilitarian mechanism, while our religious concepts are saturated in the language of money and debt. Clayton Crockett is right to argue that any philosophy of religion that does not take up directly the omnipresence and apparent omnipotence of global capital is a philosophy of outmoded religiosity, if not a necrotic theology of a dead God (Crockett et al., 2014, p. 2).

In response to this challenge it is the imagination that is the key to a robust sense of the good life. It inspires us 'to act for what is possible and not settle for things as they are, and helps us see the fullness of the humanity of those with whom we live' (Glaude, 2016). It has the potential to stimulate radical change by envisioning what might be over and against what is. In doing this, it can offer a vigorous response to the prevalent nihilism, which denies any hope that we can make sense of the world, and to the extremisms which rush to fill this void (Anderson, 2012, p. 118). Concepts of God, nature and human beings have too often been structured by the scientistic imaginary in the context of white supremacy, patriarchy, and a metaphysics of debt, which in turn feeds back to justify and reinforce the structures of oppression. The philosophy of religion must therefore endeavour to disrupt the co-opting of religion by those who support racism, misogyny and environmental destruction through the promotion of lies. The need to reimagine the future is pressing.

Beauty: the catalyst of ethical transformation. The yearning for truth is thus an undertaking at once both ethical and political. It gives us the epistemic humility to recognise how our knowing is shaped by our social contexts, including race and gender, but it also gives us the imperative to transform ourselves. The yearning for truth and goodness is emotive and desirous because truth is attractive, characterised by beauty. This means transformation is best expressed in terms of the aesthetic: the activity of imagination is essentially aesthetic contemplation. Such a model instils the philosophy of religion with a form of activity missing from models of inference.

The site of the aesthetic for Wynn is the body in its reaction to place. Knowledge of place and space is not articulated in words 
but embodied in the body's aesthetic response. It is in our sensory experiences that religious insights are presented to us most vividly (Wynn, 2013, p. 15). The aesthetic is made central to Wynn's philosophy of religion precisely because sensory experience is the key to enlightenment. Phenomenal experience is crucial to the search for wisdom. He contrasts this with the more passive 'looking' that characterises Reformed epistemology and the induction of the evidentialist approach (Wynn, 2009, pp. 7-8). The active nature of contemplation is also made explicit in Hedley's Platonic account of imagination. In the move away from a focus on propositions that are either true or false towards aesthetic contemplation, Hedley appeals to the Plotinian continuity between the physical and intelligible cosmos and the delight of beauty (Hedley, 2016, p. 20; Plotinus, 1966, I.6.2, 7-11) The soul finds joy in the intelligible and is drawn towards it. Vision is thus prioritised over discursive reflection and participation is both active and receptive (Hedley, 2016, p. 24). In going beyond the facts (the scientific gaze looking 'downwards'), the act of contemplation is a moral and aesthetic experience (Hedley, 2016 , p. 67). Images, whether objects of art, or the world itself as icon, are not merely representative but participate in their archetype and it is the aesthetic experience through their contemplation which sparks the ethic of transformation.

It must be acknowledged that Platonic ideas of beauty have been problematic for feminist thinkers because of the connection between beauty and sensuous nature (Anderson, 2012, p. 159). Images of physical beauty are said to spark the ascent of the soul: an ascent most commonly interpreted as an escape from the physical world to an alternative 'realm' beyond or above material reality. Women have typically been associated with muchmaligned matter and the male with the superiority of disembodied intellect. There is grave danger in any philosophy of religion that seeks release from the body in its yearning for the 'infinite' epitomised, as Grace Jantzen points out, by analytic arguments for the two mutually supporting poles of disembodied self and immaterial divine (Jantzen, 1999, pp. 28-29). What has already been said above about the Platonic commitment to continuity between the physical and intelligible, however, makes it clear that this is not the inevitable consequence of Platonism. It can in fact serve as a dynamic resource with which to challenge pervasive dualisms between matter and spirit, nature and human, because it does not necessarily seek the abandonment of matter. Matter without mind is a phantom Plotinus tells us: if God is not in nature, God is not in you (Clark, 2000, p. 88; Plotinus, 1966, III.6.7; II.9.16) Furthermore, a Platonic aesthetic has the potential to supplement Anderson's feminist 're-visioning' of beauty precisely because of its emphasis on the active and transformative nature of contemplation.

Anderson appeals to Iris Murdoch's Platonically informed vision of beauty as a way of elucidating how careful attention to reality might initiate the transformation required of standpoint epistemology. Murdoch's aesthetics rest on the Platonic dictum that beauty is the most accessible of the Forms and therefore acts as the catalyst of moral change. Good art shows us reality truthfully, which is why the enjoyment of art is training in the love of virtue (Murdoch, 2001, p. 86). For Murdoch, attending to beauty, be it instantiated in a piece of art or a hovering kestrel, reorientates us away from a selfish focus inwards and towards the Good perceived of as inexhaustible reality. Attention to beauty is vital in overcoming the shadows of the Platonic cave through destroying false images and false goods. It leads ultimately to clarity of vision, which in Murdoch's philosophy 'is the result of moral imagination and moral effort' (Murdoch, 2001, pp. 36, 41).

Anderson suggests such an account of attention and its commitment to the idea of truth makes it possible to accommodate postmodern concerns about our racial, gendered and ethnic biases (Anderson, 2012, p. 164). She sees judgements of beauty as a form of inter-subjective communication (Anderson, 2012, p. 160). Beauty thus becomes the communicating of beauty (conceived of as a just vision) from one to another. It is focused outwards away from the individual and inevitably encompasses the promotion of just ways of living together. Using Murdochian language, she posits beauty and unselfish attention as the two necessary features of any guide to perceiving gender injustice and also for re-visioning injustice into justice through love (Anderson, 2012, p. 173). Utilising Murdoch's Platonism in conjunction with hooks' appeal for us to 'see' in a new way that is at once material, moral and metaphysical, enables Anderson's standpoint epistemology to hold fast to a critical conception of reality while demanding the consideration of, and attempt to overcome, false versions of neutrality. The ethical conception of beauty that Anderson wishes to promote by envisaging beauty as seeing things rightly or justly (Anderson, 2012, p. 160) therefore has a precedent in the Platonic connection between the Good, the True and the Beautiful. It is this connection that lies behind Murdoch's description of the magnetic quality of the Good and it connects the aesthetic with ethics (Murdoch, 2001, p. 41). The contemplation of material reality is thus made inescapably moral.

Wynn comes closest to Anderson's standpoint epistemology and to its ethical and political implications in his commitment to overcoming a false egocentric gestalt through the aesthetically engaged 'epiphanic' experience. He also draws on Murdoch using her philosophy to illustrate how the felt distinction between subject and object is broken down through phenomenal experience: for Murdoch this happens through attending to a hovering kestrel, for Wynn through the fixing of his attention on a randomly chosen strand of grass in childhood (Wynn, 2013, p. 157). Concentration on these material things can thus redefine the sense of self (Wynn, 2013, p. 158). To experience a nonhuman animal or any aspect of the wider cosmos independently from any question of its usefulness implies, 'a liberation from any concern to bend the world to my will' (Wynn, 2013, p. 132). It is in this moment that we are lifted out of our egocentric perspective. This is essentially the process of transformation described in the previous section above. Furthermore, the significance of the moment goes beyond its immediate duration because this way of attending can secure a lasting transformation in our way of experiencing the world (Wynn, 2013, p. 133). This epistemology calls for a deeper attentiveness to reality and it requires an altered sense of self.

Wynn's concern for the emotions together with his awareness of the ethical nature of our gestalt compliments Anderson's account of attention and is an essential step in the struggle to achieve a standpoint of justice. He is not claiming merely that humans have the capacity to evaluate perceptions but rather that we can organise our perceptions according to different values. Our value schemes, he points out, enter into the very experiences we have (Wynn, 2013, p. 196). He makes the ethical hue of our religious concepts and experiences central to his philosophy of religion. In his treatment of space, he shows sensitivity to the political implications of overcoming dualism by highlighting how the meaning of space and place is apprehended by the body rather than by the 'mind'. The organisation of space can serve certain interests and oppress others. Space and power are thus interconnected and political values are part of a particular disposition of space (Wynn, 2009, p. 121). There is a consideration here of the power of myth. Space is organised through stories, or myths, and we can think of the world as a place whose sense is given in the stories of creation, reconciliation and redemption. Moreover, it may be supposed that these stories fix the meaning of various behaviours (Wynn, 2009, p. 79). Stories and myth thus shape place as much as they shape our 
sense of self. As Wynn puts it, a Christian and/or Platonic worldview that is centred on the normative insights that cannot be separated from our phenomenal experience will refocus our attention on the ethical and other challenges that are posed by the realm of the sensory (Wynn, 2013, p. 41).

This aesthetic thus marks a political turn. At the heart of this new vision of philosophy of religion lies an essential connection between beauty and justice. Anderson puts it that gaining wisdom cannot happen outside of ethical and social practices: in order to seek wisdom we must cultivate dispositions that are loving and attentive to others (Anderson, 2012, p. 202). She articulates the radical implications of the inseparable Platonic Good, True and Beautiful when she points out, drawing on hooks, that beauty cannot be forced apart from our material existence, metaphysical perception and, perhaps most importantly, our political passion (Anderson, 2012, p. 165). Crucial to this ethico-political philosophy of religion is the role of the imagination in creating a 'new vision' brought about by reconfiguring old myths and narratives about gender relations, human beings and their relations, and divine beings, all of which have the capacity to bring about new life (Anderson, 2012, p. 173).

Hedley's approach has common ground with Anderson's through the metaphysics of participation. It is the image that participates in the transcendent according to Hedley. Although this metaphysics is not as explicit in Anderson, it is apparent in the way she talks about the ethical import of myth. Myths and imaginary are the means by which we gain more truthful vision and the means by which myth can participate in reality. It is therefore through myth that justice is instantiated and beauty made real. Justice and Beauty, the Good and the True, thus participate in physical reality. This is how images function for Hedley and it gives them both a shared metaphysics.

This could be worrying from a feminist perspective: many myths and symbols are deeply gendered, racist and profoundly damaging. There is openness in Hedley's approach, however, to incorporate Anderson's call for a 'process of uncovering and reconfiguring beliefs as embedded and variously configured in myths' (Anderson, 2001, p. 6). The emphasis for Hedley, just as much as for Anderson, is not on the justification of belief but on the transformation of the knower. The 'immutability' of the Good means that it demands on-going attention and refuses to bend to the force of will. The Good and the Beautiful are not abstract ideals but regulative and moral creative energies that enable the world to be seen and experienced as interconnected cosmos, replete with inherent value (Corrigan, 2012, p. 25; Hedley, 2016, p. 72). Platonism demands the crafting of new myths and stories, and the creation of new images, all more fully aligned to what is good and truthful.

\section{Conclusion}

Anderson, Hedley and Wynn have different immediate concerns in their philosophical approaches to religion but this does not preclude the possibility of meaningful dialogue between them. Although, for example, Hedley is not concerned with scrutinising the philosophy of religion for gender injustice, and although Anderson's standpoint epistemology would most likely interrogate Burkean and other conceptions of imagination from the perspective of gender, the Platonism on which Hedley draws lends itself to Anderson's concerns and is in harmony with her broad project of reimagining the philosophy of religion.

Such a reimagined philosophy of religion prioritises the Good, the True and the Beautiful in opposition to the assertion of power and dominance of will. In this it is entirely in keeping with the aims aspired to by Ralph Cudworth. Anderson, Hedley and Wynn show how the philosophy of religion can model itself as freedom from the exertion of power through the practice of seeking truth. This is a vital task if philosophy of religion is to overcome oppressive practices by critiquing its own norms and questions but also if it is to imagine new futures and innovate. The philosophy of religion with the best prospects is thus one that promotes re-imagining and transformation, rather than apologetics (justification, warrant and basicality of belief). Such a focus will help to build bridges between Anglo-American and Continental traditions of thought and it will heed Victoria Harrison's call for philosophy of religion, ethics and metaphysics to be brought closer together (Harrison, 2011, p. 42). Envisaged in this way philosophy of religion is better able to consider the urgent problems it needs to face, especially those pertaining to relevance.

As part of this task, the philosophy of religion must involve uncovering the workings of dominant narratives. Hannah Arendt reminds us that race, religion and politics can all too often produce narratives that sustain a totalitarian system of control (Arendt, 2017). An expanded ethico-political concept of reason should, for example, include reflection on how certain concepts of God have been used to bolster white supremacism, nationalism, patriarchy, and an economics of debt (Rose, 2016, p. 4). In so doing, the philosophy of religion can help supply a much-needed different, more hopeful, imaginative vision. Only a commitment to truth can underpin a vision robust enough to challenge a posttruth world where religious beliefs-including those about the prosperity gospel or the need to hasten the coming of the endtimes through war-shape political and economic decisions that result in poverty for millions, the instigating of military conflicts, and the destruction of the biosphere. To practice standpoint epistemology and to embrace a Platonic commitment to the Good, the True and the Beautiful, is to engage in truth telling. It is to be in solidarity with others and to work with them to make our own vision of the world more strongly objective, truthful and just.

Received: 28 February 2018 Accepted: 1 October 2018

Published online: 30 October 2018

\section{References}

Anderson PS (2013) Feminist perspectives on natural theology. In: Re-Manning R, Brooke JH, Watts F (eds.) The Oxford handbook of natural theology. Oxford University Press, Oxford, p 354-369

Anderson PS (2012) Re-visioning gender in philosophy of religion: reason, love and epistemic locatedness. Ashgate, Aldershot

Anderson PS (2001) The case for a feminist philosophy of religion: transforming philosophy's imagery and myths. Ars Disput 1:1-17

Arendt H (2017) The origins of totalitarianism. Penguin, London

Carlisle J, Carter J, Whistler D (2011) Editor's introduction. In: Carlisle J, Carter J, Whistler D (eds) Moral powers, fragile beliefs: essays in moral and religious philosophy. Continuum, London, $\mathrm{p}$ xi-xxiv

Carroll TD (2016) The problem of relevance and the future of philosophy of religion. Metaphilosophy 47:39-58

Clark SRL (2009) What has Plotinus' one to do with God? In: Cornwell J, McGhee M (eds) Philosophers and God: at the frontiers of faith and reason. Continuum, London, p 21-37

Clark SRL (2000) Biology and Christian ethics. Cambridge University Press, Cambridge

Corrigan K (2012) Religion and philosophy in the platonic tradition. In: Corrigan K, Turner JD, Wakefield P (eds) Religion and philosophy in the Platonic and neoplatonic traditions: from antiquity to the early medieval period. Academia, Sankt Augustin, p 19-34

Corrigan K (2009) Ecology's future debt to Plotinus and Neoplatonism. In: Vassilopoulou P, Clark SRL (eds) Late antique epistemology: other ways to truth Palgrave Macmillan, Basingstoke, p 250-268

Corrigan K (2005) Reading Plotinus: a practical introduction to neoplatonism. Purdue University Press, West Lafayette, Indiana

Corrigan K, Harrington M (2013) Religious Platonism: philosophy and religion in the Platonic tradition. In: Christensen LB, Hammer O, Warburton DA (eds) The handbook of religions in ancient Europe. Acumen, Oxford, p 263-277 
Crockett C, Putt BK, Robbins JW (2014) Introduction: back to the future. In: Crockett C, Putt BK, Robbins JW (eds) The future of continental philosophy of religion. Indiana University Press, Bloomington \& Indianapolis, p 1-18

Cudworth R (1845) The true intellectual system of the universe. 4 Vols. Thomas Tegg, London

Draper P, Schellenberg JL (2017) Renewing philosophy of religion: exploratory essays. Oxford University Press, Oxford

Glaude ES (2016) America is suffering a crisis of imagination. Time, 24 February. http://time.com/4235720/democrats-sanders-clinton-black-voters/

Harris HA (2004) A theological approach. In: Anderson PS, Clack B (eds) Feminist philosophy of religion: critical readings. Routledge, London, p 73-86

Harris HA (2001) Struggling for truth. Fem Theol 28:40-56

Harrison VS (2011) What's the use of philosophy of religion? In: Harris HA (ed) God, goodness and philosophy. Ashgate, Farnham, p 29-43

Hedley D (2016) The iconic imagination. Bloomsbury, London

Hedley D (2008) Living forms of the imagination. T\&T Clark, London

Hedley D (2007) Real atheism and Cambridge Platonism: men of latitude, polemics, and the great dead philosophers. In: Corrigan K, Turner JD (eds) Platonism: ancient, modern, and postmodern. Brill, Leiden, p 155-173

Hickman L (2017) Eighteenth century dissent and Cambridge Platonism: reconceiving the philosophy of religion. Routledge, New York, NY

Hooks B (1999) Remembered rapture: the writer at work. The Women's Press, London

Hooks B (1994) Teaching to transgress: education as the practice of freedom. Routledge, London

Jantzen GM (2004) Foundations of violence: death and the displacement of beauty. Routledge, London

Jantzen GM (1999) Becoming divine: towards a feminist philosophy of religion. Indiana University Press, Indiana

Kanaris J (2018) Reconfigurations of philosophy of religion: a possible future. State University of New York, New York, NY

Knepper TD (2014) The end of philosophy of religion? J Am Acad Relig 82 (1):120-49

Levine MP (2000) Contemporary Christian analytic philosophy of religion: biblical fundamentalism, terrible solutions to a horrible problem, and hearing God. Int J Philos Relig 48(2):89-119

Loftus J (2016) Unapologetic: why philosophy of religion must end. Pitchstone Publishing, Durham, NC

Mooney EF (2014) On faith, the maternal, and postmodernism. In: Crockett C, Putt BK, Robbins JW (eds) The future of continental philosophy of religion. Indiana University Press, Bloomington \& Indianapolis, p 59-79

More H (1660) An explanation of the grand mystery of Godliness. J Flesher for W Morden, London

Muirhead JH (1931) The platonic tradition in Anglo-Saxon philosophy. Macmillan, London

Murdoch I (2001) The sovereignty of good. Routledge, London

Oppy G (2014) Reinventing philosophy of religion: an opinionated introduction. Palgrave Macmillan, Basingstoke
Nagasawa Y (2012) Scientific approaches to the philosophy of religion. Palgrave Macmillan, Basingstoke

Plato (1975) The Laws (trans: Saunders TJ). Penguin, London

Plotinus (1966) Enneads. Heinemann, London

Rose M (2016) It's not the money but the love of money that is the root of all evil: social subjection, machinic enslavement and the limits of Anglican social theology. Religions 7:1-12

Taliaferro C (2005) Evidence and faith: philosophy and religion since the seventeenth century. Cambridge University Press, Cambridge

Trakakis N (2008) The end of philosophy of religion. Continuum, London

Wildman WJ (2010) Religious philosophy as multidisciplinary comparative inquiry: envisioning a future for the philosophy of religion. State University of New York, New York, NY

Wynn MR (2013) Renewing the senses: a study of the philosophy of theology of the spiritual life. Oxford University Press, Oxford

Wynn MR (2009) Faith and place: an essay in embodied religious epistemology. Oxford University Press, Oxford

\section{Data availability}

All data generated or analysed during this study are included in this published article.

\section{Additional information}

Competing interests: The authors declare no competing interests.

Reprints and permission information is available online at http://www.nature.com/ reprints

Publisher's note: Springer Nature remains neutral with regard to jurisdictional claims in published maps and institutional affiliations.

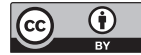

Open Access This article is licensed under a Creative Commons Attribution 4.0 International License, which permits use, sharing, adaptation, distribution and reproduction in any medium or format, as long as you give appropriate credit to the original author(s) and the source, provide a link to the Creative Commons license, and indicate if changes were made. The images or other third party material in this article are included in the article's Creative Commons license, unless indicated otherwise in a credit line to the material. If material is not included in the article's Creative Commons license and your intended use is not permitted by statutory regulation or exceeds the permitted use, you will need to obtain permission directly from the copyright holder. To view a copy of this license, visit http://creativecommons.org/ licenses/by/4.0/.

(C) The Author(s) 2018 